\title{
UCLA
}

Mester

Title

O papagaio

Permalink

https://escholarship.org/uc/item/6t7181dd

Journal

Mester, 13(2)

Author

Krueger, Robert

Publication Date

1984

DOI

10.5070/M3132013736

Copyright Information

Copyright 1984 by the author(s). All rights reserved unless otherwise indicated. Contact the author(s) for any necessary permissions. Learn more at https://escholarship.org/terms

Peer reviewed 


\section{o papagaio}

papagaio falante, sertanejo

de Guimarães Rosa

morreu,

perto do sexto aniversário da morte

do autor,

numa gaiola no pátio dum apartamento

em Copacabana,

onde um estudante norteamericano,

às pedidas tristes da viúva e da cozinheira

do autor encantado,

enterrou o papagaio no jardim

ao baixo da janela do escritório do autor, onde o estudante estudava

os rascunhos originais do Grande Sertão.

Alguns acusam o estudante

de imperialismo intelectual

por matar o espírito e a língua

do grande poeta místico

mineiro nacional brasileiro universal cósmico!

Mas o papagaio não falava cá como falará lá, verbo viravirou verba,

palavra contava ouro,

tomou conta do poeta

que ensinou o papagaio

não voante. 